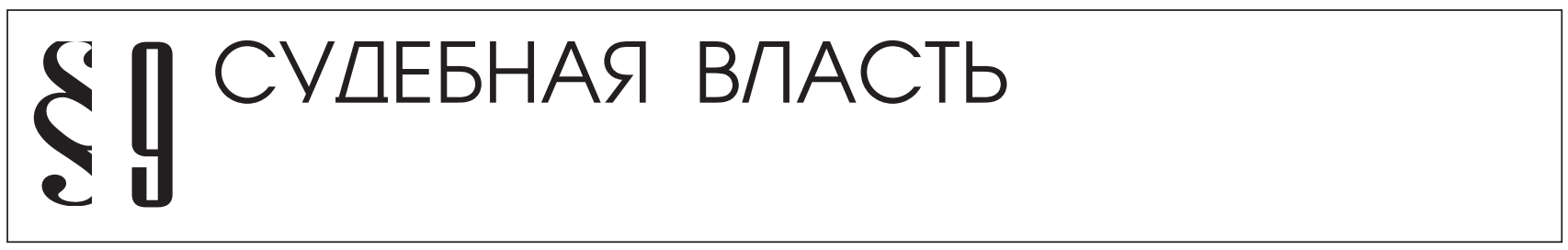

Мильчакова О.В.

\title{
ПРАВО И ПОЛИТИКА В ДЕЯТЕЛЬНОСТИ КОНСТИТУЦИОННОГО СУДА ХОРВАТИИ
}

Аннотация: Статья посвящена одной из актуальньх в настоящее время тем-соотношении права и политики в деятельности Конституционного суда. Рассмотрение отдельных аспектов соответствуюшей проблемы проводится на основе исследования конституционно-правового статуса и практики деятельности Конституционного суда в Республике Хорватии.Хорватия совсем недавно вступила в Европейский союз (с 1 июля 2013 г.). Неминуемо приближаются датьл окончания сроков мандатов у половинь состава Конституциионного суда Хорватии (2015 г.), а законодательство позволяет парламенту избрать одних и тех же лии на должности конституциионных судей на новый срок. При таких обстоятельствах весьма интересно провести наблюдение за практической деятельностью Конституционного суда с тем, чтобь понять, может ли Суд проявить необходимую органу конституционного контроля стойкость, отстраняясь от политики и разрешая исключительно вопросы права. В ходе анализа конституциионно-правового статуса и практики деятельности Конституционного суда автором преимущественно использованы формально-юридический, сравнительно-правовой и статистический методы. В статье комплексно рассматриваются установленные в Хорватии законодательнье конструкции, с одной стороны, призванные обеспечить политический нейтралитет Конституционного суда, а с другой стороны, даюшие Суду возможность открыто вмешиваться в политическую дискуссию. Выводы о соотношении права и политики в деятельности Конституциионного суда сделаны автором на основе анализа ряда громких дел: «О сексуальном просвещзении», «Об обязательной вакцинациии», «О медицинском оплодотворении», «О запрете однопольх браков». Abstract: The article is devoted to one of the topical current issues: correlation of law and politics in the activities of the Constitutional Court of Croatia. The studies of various aspects of the relevant problems is based upon the studies of the constitutional legal status and practice of the Constitutional Court in the Republic of Croatia. Croatia joined the European Union just recently (from July 1, 2013). The date when the mandates of half of the judges of the Constitutional Court of Croatia expires (2015) is drawing near, and the legislation allows the parliament to elect the same persons for the positions of constitutional judges for a new term. In such a situation, it is quite interesting to follow the practical activities of the Constitutional Court in order to establish whether the Court is capable of being sufficiently independent of politics dealing solely with legal matters in the process of constitutional control. In the course of the analysis of constitutional legal status and practice of the Constitutional Court the author mostly used formal legal, comparative legal and statistical methods. The article provides a complex evaluation of the legislative constructions provided in Croatia, which on the one hand are aimed at guaranteeing political neutrality of the Constitutional Court, while on the other hand providing the Court with the possibility to directly interfere in the political discussions. The author drew her conclusions on the correlation between law and politics in the activities of the Constitutional Court based on a number of "headline-making cases", such as "On Sexual Education", "On Obligatory Vaccination”, “On Medical Fertilization”, "On Prohibition of Same-Sex Marriages”. Ключевые слова: Конституционный суд, Хорватия, Конституциионное правосудие, Конституционный контроль, Конституциионность медицинского оплодотворения, Конституционность обязательной вакцинации, Запрет однопольх браков, Усмотрение Конституцчионного суда, Доктрина «политического вопроса», Политизированность конституциионного правосудия.

Keywords: Constitutional Court, Croatia, constitutional justice, constitutional control, constitutionality of medical conception, constitutionality of medical fertilization, constitutionality of obligatory vaccination, prohibition of same-sex marriages, discretion of the Constitutional Court, "political issue" doctrine, political character of constitutional justice.

равовая доктрина исходит из того, что конституционный суд (впрочем, как и другие судебные органы) не является сугубо политическим органом, осуществляет правоприменение и должен разрешать исключительно вопросы права, оставаясь при этом вне политики. Законодательство демократических государств стремится заложить такие принципы регулирования статуса и деятельности 
конституционного суда, которые призваны обеспечить автономию этого органа от других государственных органов и политических предпочтений, объективность и беспристрастность конституционного правосудия. Однако, как известно, практика не всегда соответствует теории и законодательным конструкциям, а вопрос об их соотношении в деятельности органов, обеспечивающих конституционность и законность в государстве, является весьма интересным, и современные реалии общественной и политической жизни заставляют уделять ему все больше внимания.

Рассматривая проблему соотношения права и политики в деятельности конституционного суда, мы обратимся к опыту Хорватии. Эта страна является одной из шести бывших югославских республик, объявивших о своей независимости после распада в начале 90-х гг. прошлого века Социалистической Федеративной Республики Югославии. В настоящее время из числа бывших югославских республик только Хорватия (с 2013 г.) и Словения (с 2004 г.) являются членами Европейского союза. При этом институт конституционной юстиции в Хорватии существует уже полвека, ведь первый Конституционный суд здесь был учрежден в 1963 г. Перечисленные факторы вызывают интерес к Республике Хорватии, а проблема соотношения права и политики в деятельности конституционного суда в любой стране актуальна сама по себе, она недостаточно исследованна в правовой науке и в политологии, в связи с чем хотелось бы поделиться некоторыми наблюдениями, характеризующими деятельность Конституционного суда Хорватии в свете упомянутой проблематики.

Как это характерно для стран с европейской (кельзианской) моделью конституционного контроля, в том числе для всех стран бывшей Югославии, в Хорватии функция конституционного контроля вверена отдельному, особому государственному органу - Конституционному суду. В Конституции ${ }^{1}$ Суду отводится отдельное место (глава V) и по итальянскому образцу он обособлен от судебной власти; Суду гарантирована административная и финансовая автономия, независимость от других органов государственной власти; конституционным судьям запрещено быть членами политических партий и своим поведением или

${ }^{1}$ Redakcijski pročišćeni tekst Ustava Republike Hrvatske, Ustavni sud Republike Hrvatske, 15. siječnja 2014. <http://www.usud.hr/uploads/ Redakcijski\%20prociscen\%20tekst $\% 20$ Ustava \%20Republike $\% 20$ Hrvatske, \%20Ustavni\%20sud\%20Republike\%20Hrvatske, $\% 20$ 15.\%20sijecnja\%202014.pdf>. (Последнее посещение: 12 апреля 2014 г.). в публичной деятельности выражать личную поддержку какой-либо партии; судьям предоставлен такой же иммунитет, как у депутатов Хорватского собора (однопалатного парламента страны); решения Суда являются обязательными для всех органов государственной власти и самоуправления, юридических и физических лиц.

Приведенные положения хорватского законодательства направлены на обеспечение политической беспристрастности и нейтральности Конституционного суда. В то же время в нем не содержится строгих требований, к примеру о том, что «контроль конституционности законов исключает какие-либо оценки политического характера» или «решения Суда выражают правовую позицию судей, свободную от соображений политической целесообразности и политических склонностей» либо «Суд не рассматривает политические вопросы».

Конституционный суд не может существовать сам по себе, вне политической сферы общественных отношений, он является одним из элементов системы государственных органов конкретной страны, осуществляющих государственную, политическую власть, некоторые из них участвуют в формировании состава Суда, а функции, возлагаемые на орган конституционного контроля, не могут в принципе оградить его от участия в политической жизни государства, поскольку многие его полномочия имеют явно политический характер.

Если говорить о Хорватии, то прежде всего, обратим внимание на порядок формирования ее Конституционного суда. Весь состав Суда (в количестве 13 членов) избирается Хорватским собором, большинством в 2/3 голосов от общего числа депутатов. Мандат судей действует 8 лет, при этом запрета на повторное избрание одного и того же лица на должность конституционного судьи не установлено. Подобное положение вещей может способствовать чрезмерной политизированности процесса избрания судей, а также ориентированию судей при реализации ими своих функций на пожелания правящей политической партии, имеющей большинство мест в парламенте. Представляется, что избрание (назначение) членов органа конституционного контроля на паритетных началах всеми тремя ветвями власти, что не является редкостью в современных государствах, функционирующих на основе принципа разделения властей, могло бы позволить уравновесить политические предпочтения законодательной власти в отношении конкретных кандидатур на должности конституционных судей (заметим, что Хорватия скорее является смешанной республикой, чем парламентской). Кроме 


\section{Право и политика $5(173) \cdot 2014$}

того, запрет повторного переизбрания на должность судьи мог бы позволить исключить неизбежные претензии к беспристрастности конституционного правосудия, обусловленные порядком формирования Суда.

С целью реализации своей основной функции по охране Конституции Суд наделен довольно обширным перечнем полномочий, некоторые из которых носят очевидный политизированный характер. К компетенции Конституционного суда относятся:

1) предварительный контроль конституционности законов и последующий контроль законов и подзаконных актов, в том числе утративших силу (традиционно составляет около 6\% в объеме работы Суда ${ }^{2}$ );

2) рассмотрение конституционных жалоб на нарушение прав и свобод человека, гарантированных Конституцией; в Хорватии предусмотрен институт полной конституционной жалобы, подаваемой против индивидуальных актов (действий), адресованных заявителю или подлежащих применению в его деле, которыми нарушены или отрицаются права и свободы человека (традиционно составляет около 90\% в объеме работы Суда);

3) надзор за конституционностью и законностью выборов, государственного референдума; разрешение избирательных споров, которые не относятся к компетенции иных судов;

4) разрешение споров о компетенции между органами законодательной, исполнительной и судебной власти, между территориальными единицами и государством;

5) надзор за конституционностью программ и деятельности политических партий;

6) рассмотрение жалоб судей на решения Государственного судебного веча об освобождении судьи от должности;

7) принятие решения об ответственности Президента Республики (производство по установлению особой ответственности Президента возбуждается парламентом, а само решение об отрешении Президента от должности принимает именно Конституционный суд, большинством в 2/3 голосов всех судей).

На наш взгляд, весьма значимыми полномочиями Суда в Хорватии, которые могут позволить ему прямо

\footnotetext{
2 Здесь и далее в статье выводы о показателях работы Конституционного суда Хорватии сделаны автором на основе анализа статистических данных, размещенных на официальном сайте Суда в сети «Интернет». $<$ http://www.usud.hr/uploads/Pregled\%20 primljenih\%20i\%20rije \%C5\%A1 enih\%20predmeta\%20od $\% 20$ 1990.\%20do\%202013.pdf $>$; $<$ http://www.usud.hr/default.aspx?Show= strateski_plan\&m1 $=22 \& \mathrm{~m} 2=98 \& \mathrm{Lang}=\mathrm{hr}>$. (Последнее посещение: 12 апреля 2014 г.).
}

влиять на государственную политику в различных сферах общественных отношений, являются: проведение мониторинга конституционности и законности в стране, сообщение о выявленных фактах неконституционности и незаконности Хорватскому собору; право расширять круг рассматриваемых в деле норм (Суд может рассмотреть конституционность и законность не только оспариваемых норм, но и всего закона или акта, других взаимосвязанных актов); возможность возбудить производство об оценке конституционности и законности актов по собственной инициативе; право отложить дату вступления в силу своего решения.

Конечно, составить представление об участии Конституционного суда в политике и о влиянии политических настроений на Суд невозможно без анализа решений, принятых им по конкретным, пожалуй, наиболее значимым для государства и общества вопросам. В связи с этим уместно обратить особое внимание на ряд дел, краткое описание которых приводим ниже.

Так, одним из резонансных для хорватского общества дел является дело «Об обязательной вакцинации», суть которого сводится к следующему. В Конституционный суд обратились физические лица и представители организации «Жизнь или вакцинация» с предложением (actio popularis) о возбуждении производства об оценке конституционности Закона о защите населения от инфекционных болезней. По мнению заявителей, установленные в Законе требования об обязательной вакцинации граждан и отказе в зачислении в дошкольные учреждения детей, которым не сделаны обязательные прививки, нарушают гарантированные Конституцией и Конвенцией о защите прав человека и основных свобод 1950 г. (Европейская конвенция) прав на здоровую жизнь, частную и семейную жизнь, самоопределение, образование, права родителей на свободу совести и самостоятельно принимать решения о лечении и иммунизации детей.

В Законе установлен перечень заболеваний (туберкулез, дифтерия, столбняк, коклюш, полиомиелит, корь, краснуха, вирусный гепатит типа «Б» и др.), в целях предотвращения которых обязательна вакцинация всех граждан без исключения. Заявители указывали, что некоторые из обязательных прививок имели значительное неблагоприятное воздействие, как в Хорватии, так и в других странах, при этом были случаи заболевания, произошедшего по причине введения вакцины. Закон лишает родителей права выбора в вопросе вакцинации своих несовершеннолетних детей. Дети, которым не сделаны обязательные прививки, не могут быть приняты в детские сады и в школы, что ограничивает их 
право на образование и необоснованно дискриминирует по сравнению с другими детьми. Ограничение права на самоопределение, по мнению заявителей, проявляется в лишении возможности самостоятельно принимать решение о лечении имедицинском вмешательстве путем введения вакцины.

Решением от 30 января 2014 г. ${ }^{3}$ Конституционный суд признал требования заявителей необоснованными, а положения Закона о защите населения от инфекционных заболеваний конституционными. Суд сослался на мнения Правительства и Министерства здравоохранения о том, что всеобщая иммунизация является одной из самых безопасных и наиболее эффективных мер в профилактике инфекционных заболеваний, встречающихся обычно в детском возрасте, когда биологические механизмы защиты организма наименее развиты. При этом случающиеся осложнения довольно редки и происходят они, как правило, в виде покраснения и боли в месте укола. Также было заявлено, что осуществление вакцинации именно в детском возрасте оказалось наиболее эффективной мерой охраны здоровья в Хорватии и в других странах мира, с помощью которой удалось ликвидировать отдельные заболевания (оспа), а некоторые из них случаются крайне редко (дифтерия, полиомиелит) или редко (корь). Родители, уклоняющиеся от вакцинации детей, угрожают здоровью своих детей, а также здоровью других лиц, вступающих в контакт с детьми.

Суд обратил внимание на положения ст. 16 Конституции, устанавливающей, что права и свободы могут быть ограничены только законом в целях защиты прав и свобод других лиц, общественного порядка, нравственности и здоровья; а в каждом конкретном случае ограничение прав и свобод должно быть пропорционально необходимости их ограничения. Согласно же ст. 69 Конституции каждый обязан, в пределах своих полномочий и деятельности, среди прочего, обращать особое внимание на защиту здоровья человека. Таким образом, законодатель пользуется свободой усмотрения в выборе мер медицинской помощи для достижения наилучших результатов в предотвращении распространения инфекционных заболеваний. Основная цель Конституции и Европейской конвенции - защита личности от произвола государственной власти. Но возлагаемые на государство обязательства по уважению и защите частной и семейной жизни могут включать в себя не только

\footnotetext{
${ }^{3}$ Rješenje. Ustavni sud Republike Hrvatske. 30. Siječnja 2014. Broj: U-I-5418/2008, U-I-4386/2011, U-I-4631/2011. <http://sljeme.usud. $\mathrm{hr} /$ usud/praksaw.nsf/ee9e09db89c968fdc1256a7f00419dff/333d1788 dda9ac94c1257c9f002f4a8d/\$FILE/U-I-5418-2008.pdf>. (Последнее посещение: 12 апреля 2014 г.).
}

позитивные, но и негативные обязательства в сфере отношений между самими частными лицами. Границы между позитивными и негативными обязательствами в рамках этих положений нелегко определить точно. Тем не менее, по утверждению Суда, государство пользуется определенной свободой усмотрения в обоих указанных контекстах. По мнению Суда, ограничения прав и свобод, предусмотренные Законом о защите населения от инфекционных заболеваний, являются соразмерными целям по охране здоровья, поэтому претензии заявителей не обоснованы.

Вопрос об обязательной вакцинации (всеобщей иммунизации) является довольно болезненным для общества и по-разному решается в различных странах мира. Так, например, заявители по упомянутому делу призывали воспользоваться опытом Бельгии, Франции, Италии, Люксембурга, Германии, Великобритании, Нидерландов и Испании, где вакцинация проводится на добровольной основе. Конституционный суд Хорватии, конечно, попытался аргументировать свою позицию о конституционности законодательных требований об обязательной вакцинации, сославшись, прежде всего, на мнения Правительства и Министерства здравоохранения. При этом очевидно, что Конституционный суд имеет и воспользовался широкой свободой усмотрения в решении вопроса о том, являются ли ограничения прав и свобод соразмерными цели, ради достижения которой они вводятся, поскольку нет каких-либо более менее объективных критериев для принятия соответствующего решения, и, по сути, Суд на них не ссылается.

Весьма интересно, что Конституционный суд не всегда считает целесообразным и возможным вдаваться в рассуждения по сути разрешаемого вопроса, как он поступил в деле «Об обязательной вакцинации». В качестве примера, иллюстрирующего сознательное отстранение Суда от высказывания позиции по содержательной части рассматриваемого вопроса, приведем дело «О сексуальном просвещении», суть которого заключается в следующем.

31 января 2013 г. Министерство науки, образования и спорта утвердило решение «О введении, мониторинге и оценке реализации Учебной программы санитарного просвещения» ${ }^{4}$.

Учебная программа, и особенно ее IV модуль «Пол. Гендерное равенство и ответственное сексу-

\footnotetext{
${ }^{4}$ Odluku o uvođenju, praćenju i vrednovanju provedbe kurikuluma zdravstvenog odgoja u osnovnim i srednjim školama. 31. Siječnja 2013. //Narodne novine broj 17/2013. <http://narodne-novine.nn.hr>. (Последнее посещение: 12 апреля 2014 г.).
} 


\section{Право и политика $5(173) \cdot 2014$}

альное поведение», предполагаемая для изучения начиная с 5-го класса школы, вызвала немало протестов родителей и правозащитных организаций. Некоторые из них обратились в Конституционный суд с предложением (actio popularis) о возбуждении производства об оценке конституционности и законности указанного решения Министерства.

Исходя из решения Конституционного суда от 22 мая 2013 г. ${ }^{5}$, позиция заявителей в основном сводилась к тому, что актом органа государственной власти осуществляется идеологическая обработка по вопросу о взаимоотношении полов, что нарушает право на свободу мировоззрения учителей, школьников и их родителей. При этом заявители выдвигали следующие доводы:

1) у Министерства отсутствовали полномочия на утверждение упомянутой учебной программы;

2) до принятия учебной программы по ней не проводились публичные слушания, она принималась почти в тайне, из процесса ее подготовки были исключены Национальный совет по образованию, представители родительских комитетов;

3) содержание IV модуля программы является не просто информативным, не является этически нейтральным, чем ограничивает право родителей выбирать способы воспитания своих детей;

4) вместо информации в программе под видом науки предлагается дезинформация, результатом чего является идеологическая обработка;

5) программой навязывается своего рода «светская религия» для детей атеистов и агностиков, поскольку содержание IV модуля программы находится в прямой оппозиции к любому конфессиональному убеждению или мировоззрению (несмотря на то, что в хорватском обществе количество людей с соответствующим мировоззрением составляет только 5,23\%);

6) материалы IV модуля программы не подходят для возраста школьников, для которых они предназначены;

7) почти половина рекомендованной литературы, которая указана в IV модуле программы, посвящена нетрадиционной сексуальной ориентации и ЛГБТмировоззрениюб

8) отдельная рекомендуемая литература даже не может быть допустима с точки зрения уголовного права

${ }^{5}$ Odluka Ustavnog suda Republike Hrvatske broj: U-II-1118/2013. Od 22. Svibnja 2013. //Narodne novine broj 17/2013. <http://narodnenovine.nn.hr>. (Последнее посещение: 12 апреля 2014 г.).

6 ЛГБТ (англ. LGBT) - аббревиатура, появившаяся в конце прошлого века в английском языке для общего обозначения сексуальных меньшинств - лесбиянок (Lesbian), геев (Gay), бисексуалов (Bisexual) и трансгендеров (Transgender). (представляющая педофилию, порнографию и проституцию как социальные явления, и не ведущая роль о том, что в соответствии с законом соответствующие действия являются уголовными преступлениями).

Конституционный суд заявил, что в данном разбирательстве не будет рассматривать материально-правовую сущность оспариваемого акта, а также значение предполагаемого воздействия, которое ему придают заявители. Одновременно Суд обратил внимание на то, что принципы, лежащие в основе демократического общества и закрепленные в статьях 1, 3 Конституции - принципы плюрализма, толерантности и свободомыслия - имеют и свой процедурный аспект. Другими словами, демократические процедуры, в круг которых входит социальный диалог по вопросам, имеющим общественный интерес, подразумевают, что сам акт, принятый в результате этих процедур, может быть определен как приемлемый с конституционно-правовой точки зрения или неприемлемый. В данном разбирательстве Суд стал рассматривать исключительно процедурный аспект оспариваемого акта.

Конституционный суд посчитал, что при утверждении Министерством науки, образования и спорта Учебной программы санитарного просвещения были нарушены процедуры принятия решений в демократическом обществе.

Конституция Хорватии (ст. 63) гарантирует право и свободу родителей самостоятельно принимать решения об образовании своих детей. При этом Конституция устанавливает и ответственность родителей за воспитание детей, которая предопределена правом каждого ребенка на полное и гармоничное развитие личности. Это означает, что право и свобода родителей самостоятельно принимать решение о воспитании своего ребенка ограничена правом самого ребенка на полное и гармоничное развитие его личности. Не вызывает сомнений, что из этого права ребенка проистекает и обязанность государства сформировать такую систему государственных школ, которая обеспечит полное и свободное развитие личности ребенка.

По смыслу ст. 63 Конституции, у государства существуют позитивные обязательства в области системы государственных школ. Из ответственности родителей по обеспечению права детей на полное и гармоничное развитие их личности проистекает и обязанность государства при утверждении учебных программ уважать различные убеждения родителей и их конституционное право и свободу самостоятельно принимать решение о воспитании детей. Это конституционное обязательство государства может быть осуществлено только путем 
привлечения родителей к процессу принятия решений о содержании учебных программ.

Поскольку при утверждении спорной Учебной программы санитарного просвещения были не соблюдены конституционные обязательства государства процедурного характера в части привлечения родителей к процессу принятия учебной программы, Конституционный суд признал неконституционным решение Министерства науки, образования и спорта об утверждении не только IV модуля «Пол. Гендерное равенство и ответственное сексуальное поведение», но и полностью всей учебной программы.

Конституционный суд Хорватии имеет, на наш взгляд, значительные возможности для манипулирования имеющимися у него полномочиями в связи с отсутствием в законодательстве жестких требований о предельном сроке рассмотрения обращений об оценке конституционности и законности актов. На практике не так уж и редки случаи рассмотрения обращений более одного года, и традиционно около $5 \%$ обращений, по которым Судом не принято решение, составляют обращения, поданные более 3 лет назад. Одним из дел, на которое хотелось бы обратить внимание в связи с высказанным доводом, является дело «О медицинском оплодотворении», касающееся следующих обстоятельств.

Подобный случай имел место, например, при принятии В 2009 г. в Хорватии был принят Закон о медицинском оплодотворении, получивший широкий общественный резонанс и споры о конституционности которого продолжаются до сих пор. Президент Хорватии С. Месич подписал этот Закон после принятия его парламентом, одновременно направив запрос в Конституционный суд о проверке его на конституционность (особенностью предварительного конституционного контроля в Хорватии является то, что проверка Конституционным судом закона не приостанавливает законодательный процесс: глава государства, направляя в Суд запрос об оценке конституционности представленного ему для подписания закона, не вправе отказаться от санкционирования и обнародования последнего).

Глава государства посчитал, что Закон нарушает принцип равенства, так как согласно его положениям, супружеская пара, желающая воспользоваться услугами медицинского оплодотворения, обязана была доказать, что семейные отношения продолжаются в течение трех лет. При этом в соответствии с хорватским законодательством одинокий человек имеет право на усыновление ребенка и не обязан доказывать наличие семейных отношений с другим человеком. Некоторые хорватские организации по защите прав женщин и один из депутатских клубов (форма объединения парламентариев на партийной основе) также направили в Конституционный суд запросы о проверке конституционности упомянутого Закона, поскольку при его применении необходимо понимать, начинается ли человеческая жизнь с момента зачатия. По их мнению, негуманными являются ограничение имплантанции только тремя эмбрионами и легализация замораживания эмбрионов. Заметим, что католическая церковь, которая имеет существенное влияние в хорватском обществе, еще в 2005 г. объявила искусственное оплодотворение преступлением.

Весьма интересно, что Конституционный суд Хорватии до настоящего времени так и не принял решение по вопросу об оценке конституционности Закона о медицинском оплодотворении. Председатель Конституционного суда Я. Омежек, комментируя фактическое приостановление конституционного производства в отношении Закона о медицинском оплодотворении, пояснила следующее: «Мы забываем основное правило, применяемое всеми конституционными судами мира, когда речь идет о чувствительном вопросе, который влияет на личную жизнь, касается проблем мировоззрения, и не только правовых, но и этических, медицинских, идеологических, религиозных и других воззрений. На самом деле, если очевидно, что демократическое обсуждение этого вопроса все еще продолжается и если ясно, что парламент не сказал своего последнего слова, то Суд не должен вмешиваться своим решением в оживленную дискуссию. Он должен тщательно следить за ее развитием и решить, требуется ли вмешательство или не связываться с этим. Здесь он действует на основе принципа самоограничения Конституционного суда ${ }^{7} »$.

Возможно, речь идет об американской доктрине «политического вопроса», сформулированной Верховным судом США, согласно которой Суд не рассматривает споры, содержащие в себе политические вопросы, а разрешает исключительно правовые вопросы. «На первый взгляд это кажется приемлемым, однако не совсем ясно, в чем состоит четкое различие между политическим вопросом, который не может разрешаться судом, и правовым вопросом, подлежащим рассмотрению в судебном порядке ${ }^{8} »$. Несмотря на то,

\footnotetext{
${ }^{7}$ Omejec J. Presudit ćemo zapošljavanju po političkim kriterijima. $<$ http://www.forum.tm/clanak/presudit-cemo-zaposljavanju-po-politickim-kriterijima-870>. (Последнее посещение: 12 апреля 2014 г.).

${ }^{8}$ Подробнее см.: Бернам У. Правовая система США. 3-й выпуск. M., 2006. C. 544.
} 


\section{Право и политика $5(173) \cdot 2014$}

что при этой доктрине отсутствуют четкие критерии для отнесения вопроса к политическому, не подлежащему разрешению в судебном порядке, Верховный суд хотя бы принимает решение в установленном порядке о том, что он не будет рассматривать спор по такой причине. Подобной практики не наблюдается в деятельности Конституционного суда Хорватии, и невзирая на заявление его Председателя о самоустранении Суда от рассмотрения отдельного вопроса, ничто не мешает Суду принять решение в момент, который «он посчитает удобным».

Действительно, конституционные суды довольно часто разрешают вопросы, имеющие резонансное значение в обществе. В подобных сложных ситуациях орган, на который возложена функция обеспечения конституционности и законности в стране, с одной стороны, должен действовать осторожно, дабы не разжечь конфликт в обществе, а с другой стороны, проявив активную позицию, учитывая нормы международного и внутригосударственного права (будь то разрешение дела по существу или официальное решение об отнесении вопроса к политическому, не подлежащему разрешению в судебном порядке), он может своим решением укрепить традиции, свойственные правовому и демократическому государству. Ведь если каждый из органов государственной власти будет самостоятельно и произвольно принимать решения о том, когда выполнять возложенные на них функции, а когда - нет, это может привести к правовому произволу, умалению авторитета институтов власти и дестабилизации общественной и политической жизни в государстве.

Со своей стороны заметим явную непоследовательность в самоустранении Конституционного суда Хорватии от решения «чувствительных для общества вопросов», касающихся права на личную жизнь и проблем мировоззрения. Обратимся, к примеру, к делу «О запрете однополых браков», суть которого сводится к следующему.

К октябрю 2013 г. католическая группа «Во имя семьи» в Хорватии собрала около 684 тыс. подписей избирателей (более $10 \%$ от общего количества избирателей) в поддержку референдума о внесении изменений в Конституцию, дающих четкое определение брака как союза мужчины и женщины. Основная цель такой инициативы заключалась в запрете однополых браков, что всячески поддерживалось Римской католической церковью, имеющей, как отмечалось, значительное влияние в хорватском обществе, и считающей, что браком является только союз, в котором могут быть рождены дети, а также оппозиционной партией «Хорватское демократическое содружество». Левоцентристское правительство выступало против введения запрета, при этом Президент И. Йосипович предупредил, что принятие таких поправок может способствовать созданию для Хорватии репутации нетолерантной страны, а Премьер-министр 3. Миланович заявил, что референдум поставит под угрозу право людей на счастье и выбор9.

Исходя из положений ст. 87 Конституции, Хорватский собор назначает референдум по предложению об изменении Конституции, принятии закона или другому вопросу, находящемуся в его компетенции, если проведения референдума потребуют не менее $10 \%$ от общего числа избирателей в Республике Хорватии. На референдуме решение принимается большинством голосов участвовавших в нем избирателей. Решение, одобренное на референдуме, является обязательным. О референдуме принимается закон.

В соответствии с Конституционным законом о Конституционном суде по запросу Хорватского собора, подаваемому в случае если $10 \%$ от общего числа избирателей в Хорватии обратились с просьбой о проведении референдума, Конституционный суд устанавливает, соответствует ли Конституции содержание вопроса, постановленного на референдум, и соблюдены ли предусмотренные частями $1-3$ статьи 86 Конституции требования для его проведения. Таким образом, Конституционный суд осуществляет предварительный контроль конституционности предложения, выносимого на референдум, а также соблюдения процедуры инициирования референдума.

Наосновеуказанныхтребованийв Конституционный суд обратился парламентский комитет по Конституции, Регламенту и Политической системе с запросом, подписанным Председателем Хорватского собора, об оценке конституционности проекта решения о назначении национального референдума о внесении изменений в Конституцию, устанавливающих четкое определение брака как союза мужчины и женщины.

Конституционный суд в ответ на упомянутый запрос 28 октября 2013 г. вынес Предупреждение ${ }^{10}$, в ко-

\footnotetext{
9 Жители Хорватии проголосовали против гей-браков. //ВВС. Русская служба. 2 декабря 2013 г. <http://www.bbc.co.uk/russian/ international/2013/12/131201_croatia_no_same_sex_marriage.shtml $>$. (Последнее посещение: 12 апреля $\overline{2} 01 \overline{4}$ г.).

${ }^{10}$ Upozorenje. Ustavni sud Republike Hrvatske. Od 24. Listopada 2013. Broj: U-VIIR-5292/2013. <http://sljeme.usud.hr/usud/praksaw. nsf/cda93f94f7a 86b1fc1256a7f0042009a/c12570d30061 ce54c1257c1 2004d2cce/\$FILE/U-VIIR-5292-2013.pdf>. (Последнее посещение: 12 апреля 2014 г.).
} 
тором, по сути, указал на несоответствие Конституции проекта выносимого на референдум вопроса: 1) с одной стороны, никаких четких запретов на вынесение отдельных вопросов в Конституции не предусмотрено; 2) с другой стороны, исходя из текста проекта, в случае одобрения решения на референдуме это будет означать возбуждение процедуры изменения Конституции, а следуя буквальному тексту Конституции (ст. 137.1), решение о возбуждении процедуры изменения Конституции принимается исключительно парламентом, большинством голосов депутатов; 3) только парламент, по мнению Суда, может принять решение о том, будет ли изменена Конституция или нет. Суд отметил существование правового пробела регламентации процедуры внесения поправок в Конституцию на основе решения, принятого на референдуме (согласно Конституции, изменения в нее вносятся парламентом по предложению уполномоченных органов власти - не менее 1/5 депутатов, Президента или Правительстваст. 136), и отсутствие практики проведения подобных референдумов в Хорватии. Использование процедур референдумов должно соответствовать правовой системе в целом, и особенно процедурным правилам, в связи с чем, по мнению Суда, необходимо оперативное принятие правовых актов, регламентирующих процесс изменения Конституции на основе результатов референдума, с тем, чтобы референдум был проведен уже на основании новых норм.

Таким образом, Конституционный суд, по сути, заявил о неконституционности планируемого референдума, хотя его позиция представляется отнюдь не безупречной: нами уже приводились положения Конституции о возможности проведения референдума по вопросу об изменении Конституции, об обязательном характере принятого на нем решения; и кажется странным, что бездействие законодательной власти по регламентации порядка реализации решения, утвержденного на референдуме, может служить поводом лишения народа гарантированного ему Конституцией права участвовать в управлении государством посредством институтов непосредственной демократии.

Несмотря на Предупреждение Конституционного суда Хорватский собор назначил референдум по вопросу о внесении изменений в Конституцию, закрепляющих понятие брака как союза исключительно мужчины и женщины. Референдум состоялся 1 декабря 2013 г. и около 65\% принявших в нем участие избирателей поддержали предложенные поправки. Результаты референдума были восприняты в хорватском обществе и в других странах как однозначный запрет однополых браков в Хорватии, введенный на конституционном уровне на основании прямого волеизъявления граждан.

Тем не менее Конституционный суд 14 ноября 2013 г. (то есть после принятия парламентом решения о назначении референдума на 1 декабря 2013 г., но до его проведения) посчитал необходимым по собственной инициативе изложить свою позицию по вопросу о состоянии конституционности в стране в связи с проводимым референдумом (подобное полномочие, как мы указывали, может быть реализовано в рамках мониторинга состояния конституционности и законности в стране и сообщения об этом парламенту).

В Сообщении от 14.11.2013 ${ }^{11}$ Суд, прежде всего, подчеркнул, что предварительный запрос об оценке конституционности выносимого на референдум вопроса был подан не парламентом, как это установлено в Конституции, а его комитетом, но из уважения к конституционной роли хорватского парламента как высшего законодательного и представительного органа в государстве, в качестве исключения может быть признано допустимым обращение рабочего органа парламента с запросом в Конституционный суд по упомянутому вопросу. Суд указал, что хотя парламент все же назначил референдум, несмотря на Предупреждение Конституционного суда о его неконституционности, Суд не может самоустраниться от контроля соблюдения конституционности при проведении такого референдума и посчитал возможным опубликовать свое Сообщение.

Суд заявил, что поскольку решение о назначении референдума было поддержано большинством членов парламента, то можно считать, что парламент выразил свою правовую волю о желании возбудить процедуру изменения Конституции (на соответствующий аргумент Предупреждения в пользу неконституционности референдума мы обращали внимание; в данном случае Суд признал это нарушение, по сути, устраненным).

Далее Конституционный суд сослался на Конвенцию о защите прав человека и основных свобод, Хартию Европейского союза об основных правах, которые не устанавливают запретов на заключение браков между людьми одного пола. Кроме того, Суд привел в пример решение Европейского суда по правам человека, вы-

\footnotetext{
${ }^{11}$ Priopćenje. Ustavni sud Republike Hrvatske. Od 14. Studenoga 2013. Broj: SuS-1/2013. <http://sljeme.usud.hr/usud/praksaw.nsf/cda93f94 f7a86b1fc1256a7f0042009a/3eb0f70a0c597481c1257c9f002f28c7/\$ FILE/SuS-1-2013\%20-\%20PRIOP\%C4\%86ENJE.pdf $>$. (Последнее посещение: 12 апреля 2014 г.).
} 
DOI: 10.7256/1811-9018.2014.5.11851

При цитировании этой статьи сноска на dоі обязательна

\section{Право и политика 5 (173) • 2014}

несенное в 2010 г. в отношении Австрии по вопросу о дискриминации в связи с запретом заключения брака между лицами мужского пола, а именно на позицию о том, что хотя некоторые государства-члены Совета Европы разрешили однополые браки, это обстоятельство отражает их собственные представления о роли брака в обществе, оно не следует из толкования основных прав, а «Европейский консенсус» в отношении однополых браков до сих пор не достигнут.

Конституционный суд обратил внимание на то, что в Хорватии с 2003 г. действует Закон об однополых гражданских союзах, который еще ни разу не был изменен или дополнен и не оспаривался в Суде. Согласно названному Закону однополый гражданский союз является объединением двух человек одного и того же пола, живущих вместе не менее 3 лет, и основывается на принципах равенства и эмоциональных отношениях между партнерами, взаимном уважении и помощи. В связи с чем Конституционный суд указал, что даже если на референдуме будет принято решение о внесении изменений в Конституцию, определяющих, что брак является союзом исключительно мужчины и женщины, данное обстоятельство не должно запрещать однополые союзы, которые будут составлять в этом случае отдельную категорию правовых отношений, наряду с официально признанным браком и гражданским браком. При этом Суд заявил, что одобрение вопроса, вынесенного на референдум, не может иметь никакого влияния на дальнейшее развитие договорно-правовых отношений между участниками гражданских браков и однополых союзов.

Таким образом, исходя из Сообщения Конституционного суда, несмотря на восприятие всеми одобрения на референдуме изменений в Конституцию как запрета на однополые браки, в том числе официально признаваемые союзы, Конституционный суд посчитал, это никоим образом не повлияет на официальное признание в Хорватии однополых союзов. Подобная позиция представляется грубым нарушением, прежде всего, принципа народного суверенитета и весьма наглядно демонстрирует возможности интерпретации одних и тех же правовых норм различным образом, в угоду определенным пожеланиям.

Конечно, можно предположить, что Конституционный суд, принимая Предупреждение и Сообщение, руководствовался, прежде всего, национальными интересами и желаниями продемонстрировать Европейскому союзу свою приверженность новейшим принципам устройства общества, ведь Хорватия вступила в ЕС совсем недавно (1 июля 2013 г.). Однако невозможно умолчать о том, что у 6 из 12 действующих в настоящий момент конституционных судей срок полномочий истекает в 2015 г., у 3 - в 2016 г., и у 3 - в 2017 г. Ранее мы уже обращали внимание на то, что в Хорватии не установлено запрета на переизбрание одного и того же лица на должность конституционного судьи, при этом судьи избираются Хорватским собором, где большинство мест принадлежит Социал-демократической партии Хорватии (последние выборы проводились в 2011 г.), а Президент и Премьер-министр, выступавшие против запрета однополых браков, являются членами этой партии. Согласитесь, при таких обстоятельствах, трудно удержаться от мыслей о возможной политической ангажированности судей при принятии Предупреждения и Сообщения.

В заключение отметим, что конституционный суд, безусловно, является не только юридическим, но одновременно и политическим органом, что предопределено его местом в системе органов государственной власти и спецификой возлагаемых на него функций и задач. Некоторые дела, рассматриваемые конституционными судами, имеют резонансное значение, при этом суд, как правило, подвергается сильному давлению со стороны общества, церкви, средств массовой информации, политических структур, в связи с чем, балансируя на грани права и политики, ему приходиться проявлять определенную гибкость в толковании конституционноправовых норм. Но конституционный суд не может и не должен превращаться в один из инструментов правящей политической элиты, что, в принципе, противоречит природе института конституционного контроля в демократическом обществе.

\section{Библиография:}

1. Арутюнян А. А. Конституционализм: проблемы постсоветской реальности. М., 2013. - 160 с.

2. Бернам У. Правовая система США. 3-й выпуск. М., 2006. - 1216 c.

3. Бондарь Н. С. Судебный конституционализм в России в свете конституционного правосудия. М., 2011. - 544 c.

4. Витрук Н. В. Конституционное правосудие. Судебно-конституционное право и процесс: учеб. пособие. - 3-е изд., перераб. и доп. М., 2011. - 592 с.

5. Конституционализм: идеал и/или реальность: Сборник материалов дискуссии за круглым столом 4 февраля 2011 года / Под ред. Б. А. Страшуна, И. А. Алебастровой. М., 2012. - 255 с. 
6. Конституционный контроль: доктрина и практика: материалы международной конференции, посвященной 20-летию Конституционного Суда Российской Федерации (Санкт-Петербург, 28-29 октября 2011 г.) / Под ред. В. Д. Зорькина. М., 2012. - 464 с.

7. Конституция в XXI веке: сравнительно-правовое исследование / Отв. ред. В. Е. Чиркин. М., 2011. $656 \mathrm{c}$.

8. Международный трибунал по бывшей Югославии: Деятельность, результаты, эффективность. Материалы Международной научной конференции (Москва, 22 - 23 апреля 2009 г.) / Отв. ред. Е. Ю. Гуськова. М., 2012. - 544 с.

9. Месич С. Как развалилась Югославия. М., 2013. $-394 \mathrm{c}$.

10. Мильчакова О. В. Конституционная юстиция в Хорватии: становление, развитие, основы организации. Монография. М., 2013. - 174 с.

11. Мильчакова О. В. Конституционный контроль в странах бывшей Югославии. М., 2014. - 308 с.

12. Нуриев Г. Х. Европейская модель конституционного судопроизводства. М., 2012. - 224 с.

13. Пономарева Е. Г. Новые государства на Балканах: Монография. М., 2010. -252 с.

14. Сергеев Д. Н. Конституционное правосудие в России: политико-правовое исследование. Дис. ... канд. полит. наук. М., 2005. - 150 с.

15. Никулин В.В. Правосудие и политика: соотношение политики и права в советской системе наказаний // NB: Исторические исследования. - 2013. - 5. - C. 1-59. DOI: 10.7256/2306-420X.2013.5.747. URL: http://www.e-notabene.ru/hr/article_747.html

16. Алфимцев В.Н. Место Конституционного Суда Российской Федерации в системе органов власти, формирующих национальную политику государства // Актуальные проблемы российского права. - 2012. - 2. - C. 56-63.

17. Марков П.В. Условия осуществления судебного усмотрения в странах континентальной и англосаксонской правовой семьи // NB: Вопросы права и политики. - 2012. - № 4. - C.73-107. DOI: 10.7256/2305-9699.2012.4.318. URL: http://e-notabene. $\mathrm{ru} / \mathrm{lr} /$ article $318 . \mathrm{html}$

18. Кананыкина Е.С. Место судебных прецедентов Америки в системе образования // NB: Проблемы общества и политики. - 2013. - № 4. - С.111-135. DOI: 10.7256/2306-0158.2013.4.457. URL: http://enotabene.ru/pr/article_457.html

19. Агеев В.Н. Правомерность ограничения прав и свобод государственных служащих в Российской
Федерации: правовая оценка Конституционного Суда // NB: Вопросы права и политики. - 2013. - № 1. - C.166-189. DOI: 10.7256/2305-9699.2013.1.394. URL: http://e-notabene.ru/lr/article_394.html

20. Мильчакова О.В.. Пределы вмешательства Европейского суда по правам человека в деятельность Конституционного суда Боснии и Герцеговины // Право и политика. - 2014. - № 2. C. 104-107. DOI: 10.7256/1811-9018.2014.2.10872

21. Есева Е.Ю. Гарантия беспристрастности российского суда. // NB: Вопросы права и политики. - 2012. - № 2. - C.49-61. DOI: 10.7256/23059699.2012.2.94. URL: http://e-notabene.ru/lr/ article_94.html

22. Кальян К.В.. Правовое регулирование сроков судебного обжалования актов налоговых органов. // Налоги и налогообложение. - 2014. - № 1. C. 104-107. DOI: 10.7256/1812-8688.2014.1.10876

23. Горелова О.А.. Проблемы привлечения судей к дисциплинарной ответственности в современном законодательстве и практике квалификационных коллегий судей // Политика и Общество. - 2014. - № 2. - C. 104-107. DOI: 10.7256/18128696.2014.2.11179

24. Соколов Т.В.. Сущность конституционного судопроизводства в контексте доктрины судебного права // Политика и Общество. - 2014. - № 2. C. 104-107. DOI: 10.7256/1812-8696.2014.2.11171

25. Шинкарецкая Г.Г.. Международный уголовный суд: попытка оценки // Международное право и международные организации / International Law and International Organizations. - 2014. - № 1. C. 104-107. DOI: 10.7256/2226-6305.2014.1.11593

26. Есева Е.Ю.. Свобода судебной власти в современной России. // Право и политика. - 2014. - № 3. C. 104-107. DOI: 10.7256/1811-9018.2014.3.5635

27. Мильчакова О.В.. Современные модели судебного конституционного контроля в странах бывшей Югославии // Право и политика. - 2014. - № 3. C. 104-107. DOI: 10.7256/1811-9018.2014.3.1132

\section{References (transliteration):}

1. Arutyunyan A. A. Konstitutsionalizm: problemy postsovetskoi real'nosti. M., 2013. - $160 \mathrm{~s}$.

2. Bernam U. Pravovaya sistema SShA. 3-i vypusk. M., 2006. - $1216 \mathrm{c}$.

3. Bondar' N. S. Sudebnyi konstitutsionalizm v Rossii v svete konstitutsionnogo pravosudiya. M., 2011.-544 s. 
DOI: $10.7256 / 1811-9018.2014 .5 .11851$

При цитировании этой статьи сноска на dоі обязательна

\section{Право и политика 5 (173) • 2014}

4. Vitruk N. V. Konstitutsionnoe pravosudie. Sudebnokonstitutsionnoe pravo i protsess: ucheb. posobie. 3-e izd., pererab. i dop. M., 2011. - 592 s.

5. Mesich S. Kak razvalilas' Yugoslaviya. M., 2013. 394 s.

6. Mil'chakova O. V. Konstitutsionnaya yustitsiya v Khorvatii: stanovlenie, razvitie, osnovy organizatsii. Monografiya. M., 2013. - 174 s.

7. Mil'chakova O. V. Konstitutsionnyi kontrol' v stranakh byvshei Yugoslavii. M., 2014. - 308 s.

8. Nuriev G. Kh. Evropeiskaya model' konstitutsionnogo sudoproizvodstva. M., 2012. - 224 s.

9. Ponomareva E. G. Novye gosudarstva na Balkanakh: Monografiya. M., 2010. - 252 s.

10. Sergeev D. N. Konstitutsionnoe pravosudie v Rossii: politiko-pravovoe issledovanie. Dis. ...kand. polit. nauk. M., 2005. - $150 \mathrm{~s}$.

11. Nikulin V.V. Pravosudie i politika: sootnoshenie politiki i prava $\mathrm{v}$ sovetskoi sisteme nakazanii // NB: Istoricheskie issledovaniya. - 2013. - 5. - C. 1-59. DOI: 10.7256/2306-420X.2013.5.747. URL: http://www.enotabene.ru/hr/article_747.html

12. Alfimtsev V.N. Mesto Konstitutsionnogo Suda Rossiiskoi Federatsii v sisteme organov vlasti, formiruyushchikh natsional'nuyu politiku gosudarstva // Aktual'nye problemy rossiiskogo prava. - 2012. - 2. - C. 56-63.

13. Markov P.V. Usloviya osushchestvleniya sudebnogo usmotreniya $v$ stranakh kontinental'noi i anglosaksonskoi pravovoi sem'i // NB: Voprosy prava i politiki. - 2012. - № 4. - S.73-107. DOI: 10.7256/2305-9699.2012.4.318. URL: http://e-notabene.ru/lr/article_318.html

14. Kananykina E.S. Mesto sudebnykh pretsedentov Ameriki v sisteme obrazovaniya // NB: Problemy obshchestva i politiki. - 2013. - № 4. - S.111-135. DOI: 10.7256/2306-0158.2013.4.457. URL: http://e-notabene. ru/pr/article_457.html

15. Ageev V.N. Pravomernost' ogranicheniya prav i svobod gosudarstvennykh sluzhashchikh v Rossiiskoi
Federatsii: pravovaya otsenka Konstitutsionnogo Suda // NB: Voprosy prava i politiki. - 2013. - № 1. S.166-189. DOI: 10.7256/2305-9699.2013.1.394. URL: http://e-notabene.ru/lr/article_394.html

16. Mil'chakova O.V.. Predely vmeshatel'stva Evropeiskogo suda po pravam cheloveka v deyatel'nost' Konstitutsionnogo suda Bosnii i Gertsegoviny // Pravo i politika. - 2014. - № 2. - S. 104-107. DOI: 10.7256/1811-9018.2014.2.10872

17. Eseva E.Yu. Garantiya bespristrastnosti rossiiskogo suda. // NB: Voprosy prava i politiki. - 2012. - № 2. - S.49-61. DOI: 10.7256/2305-9699.2012.2.94. URL: http://e-notabene.ru/lr/article_94.html

18. Kal'yan K.V.. Pravovoe regulirovanie srokov sudebnogo obzhalovaniya aktov nalogovykh organov. // Nalogi i nalogooblozhenie. - 2014. - № 1. - S. 104-107. DOI: $10.7256 / 1812-8688.2014 .1 .10876$

19. Gorelova O.A.. Problemy privlecheniya sudei k distsiplinarnoi otvetstvennosti $\mathrm{v}$ sovremennom zakonodatel'stve i praktike kvalifikatsionnykh kollegii sudei // Politika i Obshchestvo. - 2014. - № 2. - S. 104107. DOI: $10.7256 / 1812-8696.2014 .2 .11179$

20. Sokolov T.V.. Sushchnost' konstitutsionnogo sudoproizvodstva $\mathrm{v}$ kontekste doktriny sudebnogo prava // Politika i Obshchestvo. - 2014. - № 2. - S. 104-107. DOI: 10.7256/1812-8696.2014.2.11171

21. Shinkaretskaya G.G.. Mezhdunarodnyi ugolovnyi sud: popytka otsenki // Mezhdunarodnoe pravo i mezhdunarodnye organizatsii / International Law and International Organizations. - 2014. - № 1. - S. 104107. DOI: 10.7256/2226-6305.2014.1.11593

22. Eseva E.Yu.. Svoboda sudebnoi vlasti v sovremennoi Rossii. // Pravo i politika. - 2014. - № 3. - S. 104-107. DOI: $10.7256 / 1811-9018.2014 .3 .5635$

23. Mil'chakova O.V.. Sovremennye modeli sudebnogo konstitutsionnogo kontrolya v stranakh byvshei Yugoslavii // Pravo i politika. - 2014. - № 3. - S. 104107. DOI: $10.7256 / 1811-9018.2014 .3 .1132$ 